\title{
Tripe Palms: A Rare Cutaneous Paraneoplastic Disorder
}

\section{Tripe Palms: Uma Síndrome Paraneoplásica Cutânea Rara}

Alexandre MIROUX-CATARINO ${ }^{1}{ }^{1}$, Leandro SILVA ${ }^{1}$, Goreti CATORZE1

Acta Med Port 2021 Jan;34(1):61-61 · https://doi.org/10.20344/amp.12661

Keywords: Acanthosis Nigricans; Keratoderma, Palmoplantar; Paraneoplastic Syndromes; Skin Diseases

Palavras-chave: Acantose Nigricans; Ceratodermia Palmar e Plantar; Doenças de Pele; Síndromes Paraneoplásicas

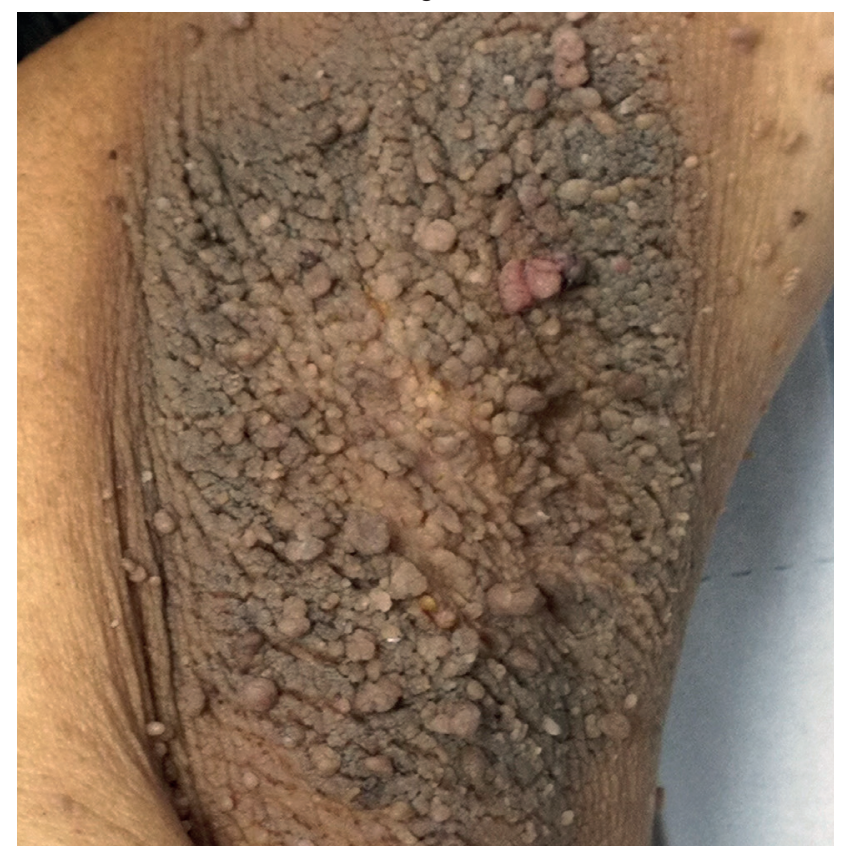

Figure 1 - Diffuse hyperpigmentation and velvety texture with papillomatosis in the left axilla

A 67-year-old woman with a 6-year history of invasive breast carcinoma with bilateral axillary lymph node metastasis presented with a diffuse hyperpigmentation and pediculated brown papules with a velvety texture in the armpit flexures (Fig. 1) and enhanced ridges and velvety hyperkeratosis involving the palms (Fig. 2). The tongue and oral mucosa had similar findings. The cutaneous lesions had an abrupt onset by the time of the diagnosis. She underwent unilateral mastectomy, radiotherapy and chemotherapy. Currently, the disease is in remission with trastuzumab and hormone therapy and a total body scan found no lesions. The diagnosis of malignant acanthosis nigricans (MAN) and tripe palms (TP) was made.

The term triple palms was coined in the literature by

PROTECTION OF HUMANS AND ANIMALS: The authors declare that the procedures were followed according to the regulations established by the Clinical Research and Ethics Committee and to the Helsinki Declaration of the World Medical Association published in 2013. | DATA CONFIDENTIALITY: The authors declare having followed the protocols in use at their working center regarding patients' data publication. | INFORMED CONSENT: Obtained. | CONFLICTS OF INTEREST: All authors report no conflict of interest. | FUNDING SOURCES: The authors declare that there were no external sources of study for the performance of this article. REFERENCES

1. Fabroni C, Gimma A, Cardinali C, Lo Scocco G. Tripe palms associated with malignant acanthosis nigricans in a patient with gastric adenocarcinoma: a case report and review of the literature. Dermatol Online J. 2012;18:15.

2. Brinca A, Cardoso JC, Brites MM, Tellechea Ó, Figueiredo A. Papilomatose cutânea florida e acantose nigricante maligna reveladoras de neoplasia gástrica. An Brasil Dermatol. 2011;86:573-7.

3. Cohen PR, Grossman ME, Almeida L, Kurzrock R. Tripe palms and malignancy. J Clin Oncol. 1989;7:669-78.

4. Chakraborty PP, Datta S, Mandal SK, Kumar M. Tripe palm: a cutaneous manifestation of gastric carcinoma. BMJ case rep. $2014 ; 2014:$ bcr2014206004.

1. Serviço de Dermatologia. Hospital Egas Moniz. Lisboa. Portugal.

$\triangle$ Autor correspondente: Alexandre Miroux-Catarino. alexandre catarino@hotmail.com

Recebido: 06 de agosto de 2019 - Aceite: 25 de setembro de 2019 | Copyright @ Ordem dos Médicos 2021 